\title{
The association of 5HT2A and 5HTTLPR polymorphisms with Alzheimer's disease susceptibility: a meta-analysis with 6945 subjects
}

\author{
Liang Tang ${ }^{1,3}$, Jianming $\mathrm{Li}^{1,2}$, Huaiqing Luo ${ }^{1,3}$, Meihua Bao ${ }^{1,3}$, Ju Xiang ${ }^{1,3}$, Yiwei \\ Chen $^{1,3}$ and Yan Wang ${ }^{1,3,4}$ \\ ${ }^{1}$ Department of Human Anatomy, Histology and Embryology, Institute of Neuroscience, Changsha Medical University, \\ Changsha, PR China \\ ${ }^{2}$ Department of Neurology, Xiang-Ya Hospital, Central South University, Changsha City, Hunan Province, PR China \\ ${ }^{3}$ School of Basic Medical Science, Changsha Medical University, Changsha, PR China \\ ${ }^{4}$ Experiment Center for Function, Changsha Medical University, Changsha, PR China \\ Correspondence to: Yan Wang, email: yanwang871214@163.com \\ Yiwei Chen, email: yiwei_chen89@163.com
}

Keywords: Alzheimer's disease (AD); 5-hydroxytryptophan 2A Receptor (5HT2A); serotonin transporter (5HTT); Apolipoprotein E (APOE); meta-analysis

Received: July 12, 2017 Accepted: November 15, 2017 Epub: December 22, 2017 Published: March 13, 2018

Copyright: Tang et al. This is an open-access article distributed under the terms of the Creative Commons Attribution License 3.0 (CC BY 3.0), which permits unrestricted use, distribution, and reproduction in any medium, provided the original author and source are credited.

\section{ABSTRACT}

Alzheimer's disease (AD) is a progressive neurodegenerative disease. Relationships of 5HT2A and 5HTTLPR polymorphisms and AD risk have been widely investigated previously, whereas results derived from these studies were inconclusive and controversial. The aim of this study was to investigate the association of the 5-HT2A and 5HTTLPR polymorphisms and AD using a meta-analysis of existing literatures. Studies were collected using PubMed, Web of Science, the Cochrane Library databases, Chinese National Knowledge Infrastructure (CNKI) and Embase. Pooled odds ratios (ORs) with $95 \%$ confidence intervals (CIs) were used to assess associations. As a result, a total of 7 publications for 5-HT2A T102C and 16 publications for 5HTTLPR (L/S) comprised 3255 cases and 3690 controls fulfilled the inclusion criteria. Significant association was covered between allelic and recessive models of 5-HT2A T102C and AD (allelic model: $p=0.003$, OR $[95 \% \mathrm{CI}]=1.23[1.07,1.40]$; recessive model: $p=$ 0.03$, OR $[95 \% \mathrm{CI}]=1.28[1.02,1.59])$. Subsequently, we conducted subgroup analysis for 5-HT2A T102C polymorphism based on ethnicities and APOE $\varepsilon 4$, and identified a significantly increased risk for the allelic and dominant models of 5-HT2A T102C and AD in Asian subgroup (allelic model: $p=0.002$, OR $[95 \% \mathrm{CI}]=1.42[1.14,1.78]$; dominant model: $p=0.02$, OR $[95 \% \mathrm{CI}]=1.60[1.09,2.35])$ and subgroup without APOE $\varepsilon 4$ (allelic model: $p=0.02$, OR $[95 \% \mathrm{CI}]=1.44[1.05,1.99]$; dominant model: $p=0.0008$, OR $[95 \% \mathrm{CI}]=2.49[1.46,4.25])$. Nevertheless, the pooled analyses suggested no significant association between allelic, dominant, and recessive models of 5HTTLPR $(L / S)$ and AD $(p>0.05)$. In conclusion, our meta-analysis demonstrates that 5HT2A C10T, but not 5HTTLPR (L/S), might increase risk for AD.

\section{INTRODUCTION}

Alzheimer's disease (AD), characterized by progressive memory and language impairment, cognitive deficits, and other behavioral and psychological symptoms of dementia (BPSD), is a progressive neurodegenerative disorder [1-2]. The mechanism of AD is complex and not well known yet. Apart from environment factors such as education level and life style, genetic contribution may partly determinate the risk of AD [3-5]. The well-studied genetic risk factor for $\mathrm{AD}$ should be the apolipoprotein E (APOE) $\varepsilon 4$ allele. It was suggested to be a susceptible 
factor to both familial and sporadic AD [6-8]. However, this variant accounts to only part of genetic susceptibility to $\mathrm{AD}$ [9]. Therefore, further gene polymorphisms may confer additional risk to develop AD.

Serotonin (5-hydroxytryptamine, 5-HT) is a key neurotransmitter involved in many aspects of psychological processes including mood, aggression, impulsivity, and anxiety in human and animal [10-13]. Serotonin dysfunction has been implicated in many psychiatric diseases including AD [14]. The action of $5-\mathrm{HT}$ is mediated by $5 \mathrm{HT}$ receptors. Multiple 5-HT receptors have been identified. Increasing evidences suggest that 5-HT receptors especially 5HT2A and 5HT1A have impartment role in the development of $\mathrm{AD}$ [15-17]. In addition, large number of neurobiological researches have suggested a decrease in density and specific binding of the 5HT2A receptor in AD patients' brain [18-19]. Following 5-HT release, the serotonin reuptake transporter (5-HTT) is thought to be the principal regulation site of the serotonin levels by facilitating reuptake of 5-HT from the synaptic cleft to its receptors in the central nervous system [20]. The 5-HTT may therefore be also involved in the pathogenesis of AD.

Polymorphisms in the serotonin-related genes were demonstrated to be associated with the risk of $\mathrm{AD}$ in recent studies. The most commonly and widely studied polymorphisms should be the 5-HT2A (C102T) and SLC6A4 (5HTTLPR) [21-23]. The 5HT2A C102T is a variant change in exon 1 that does not alter the serine at position 34 and was shown to contribute to lower transcriptional activity than the 5HT2A $102 \mathrm{C}$
[24]. Increasing case-control studies have investigated the association of 5-HT2A C102T and AD and reported conflict results. While, most of the studies revealed negative results [21, 25-26]. As for 5-HTTLPR, an insertion or deletion of a 44-bp fragment in the promoter region of 5-HTT gene (SLC6A4), was found to regulate 5 -HTT promoter activity by cAMP and protein kinase $\mathrm{C}[27,29]$. The short (S) allele (deletion) is associated with a lower rate of 5HTT transcription than the long (L) allele (insertion) and therefore may reduce 5HT reuptake capacity and lead to alterations in serotonergic neurotransmission $[28,30]$. The genetic correlation of 5-HTTLPR (L/S) and AD was firstly identified by Li et al. in British population [31]. However, this positive result can only be replicated in several Caucasian populations [32-33], but not in Asian populations [34-36]. These discrepancies may be due to insufficient calculated power, different ethnicities, and limited sample sizes in individual studies.

In light of these controversial and inconclusive observations, we conducted a meta-analysis to investigate the possible role of 5-HT2A (C102T) and 5HTTLPR (L/S) polymorphisms in susceptibility of AD.

\section{RESULTS}

\section{Characteristics of the published studies}

As shown in Figure 1, we initially retrieved 441 articles (297 for 5HT2A and 144 for 5HTTLPR) from databases. After screening the titles, abstracts, and full text,

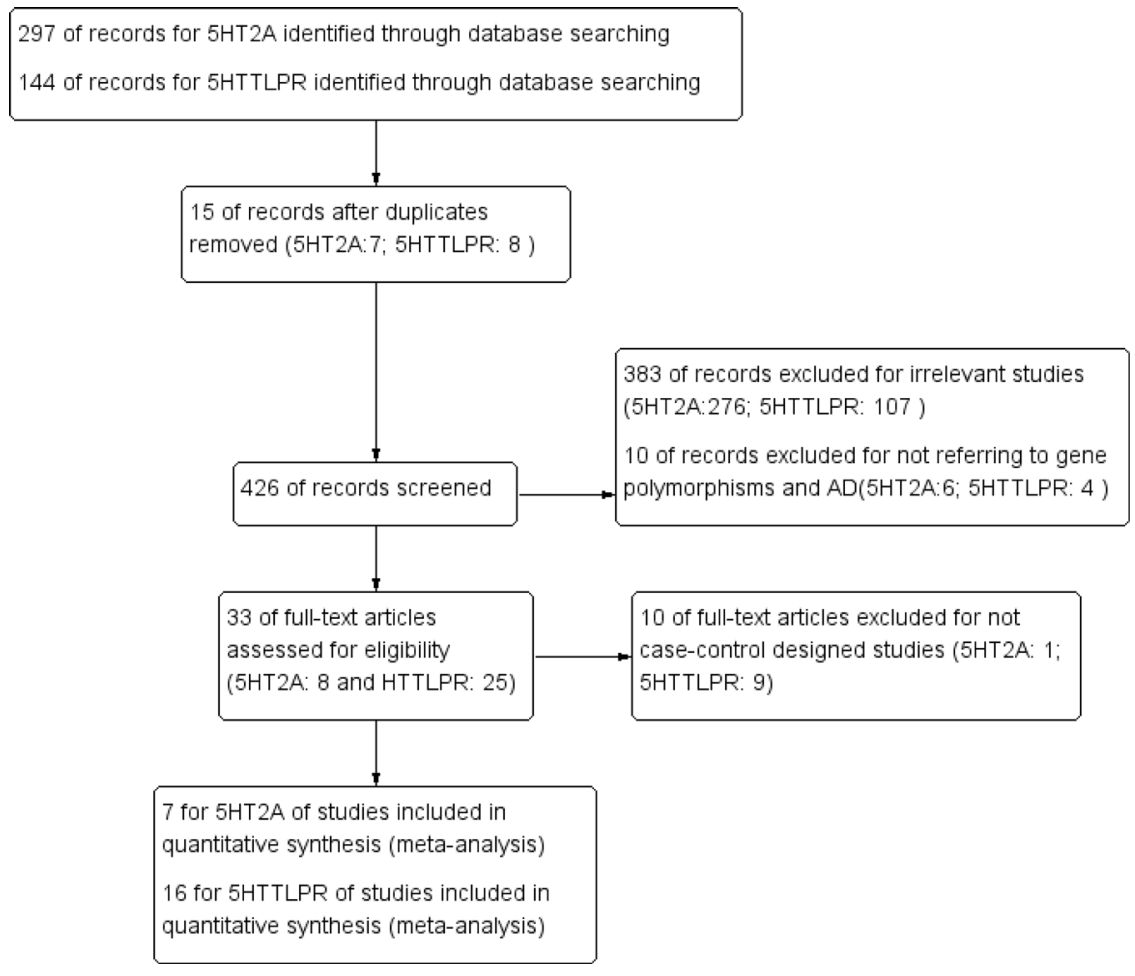

Figure 1: PRISMA flow chart of studies inclusion and exclusion. 
15 were excluded for duplicated studies ( 7 for 5HT2A and 8 for 5HTTLPR). 383 were excluded for irrelevant studies (276 for 5HT2A and 107 for 5HTTLPR). 10 were excluded for not referring to the genetic association of 5-HT2A T102C and 5HTTLPR (L/S) and AD (6 for 5-HT2A T102C and 4 for 5HTTLPR (L/S)). 10 were excluded for not case-control designed studies (1 for 5HT2A and 9 for 5HTTLPR). Finally, a total of 7 articles for 5HT2A C102T [22, 25-26, 37-40] and 16 articles for 5HTTLPR (L/S) [1, 22-23, 31-36, 40-46] involving 3255 cases and 3690 controls were recruited in the present meta-analysis. For 5HT2A C102T, there were 4 studies referring to Caucasians [22, 26, 37, and 40] and 3 studies referring to Asians [25, 38-39]. In addition, 2 studies reported APOE $\varepsilon 4$ (with/without) subtypes of $\mathrm{AD}$ cases and controls [38-39]. As for 5HTTLPR (L/S), there were 12 studies referring to Caucasians [1, 22-23, 31-33, 40, 42-46] and 4 studies referring to Asians [34-36, 41]. In addition, 5 studies reported APOE $\varepsilon 4$ (with/without) subtypes of
AD $[33,35-36,42,44]$. The genetic distributions of the control group in individual study were consistent with the Hardy-Weinberg equilibrium (HWE). The NewcastleOttawa Scale (NOS) [47] was used for quality assessment. And all of the studies achieved moderately high quality scores above 7 (Table 1, Supplementary Table 1).

\section{Meta-analysis: 5HT2A (C102T) and Alzheimer's disease}

The main results of the meta-analysis of the association between 5HT2A (C102T) and AD are listed in Table 2. A total of 7 articles including 1011 cases and 848 controls were recruited. Increased AD risk could be shown in both the allelic $(\mathrm{OR}=1.23 ; 95 \% \mathrm{CI}=1.07-1.40)$ and recessive models $(\mathrm{OR}=1.28 ; 95 \% \mathrm{CI}=1.02-1.59)$, but not in dominant model $(p=0.08)$ of 5HT2A C102T (Figure 2). Subgroups analysis based on ethnicities showed a significant association between allelic and

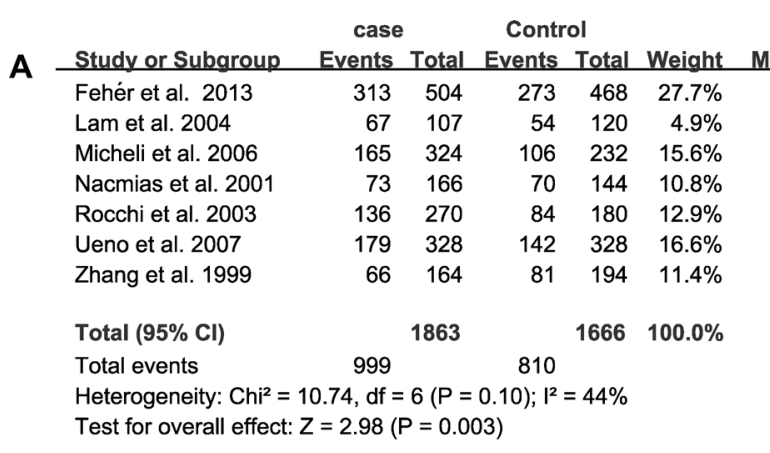
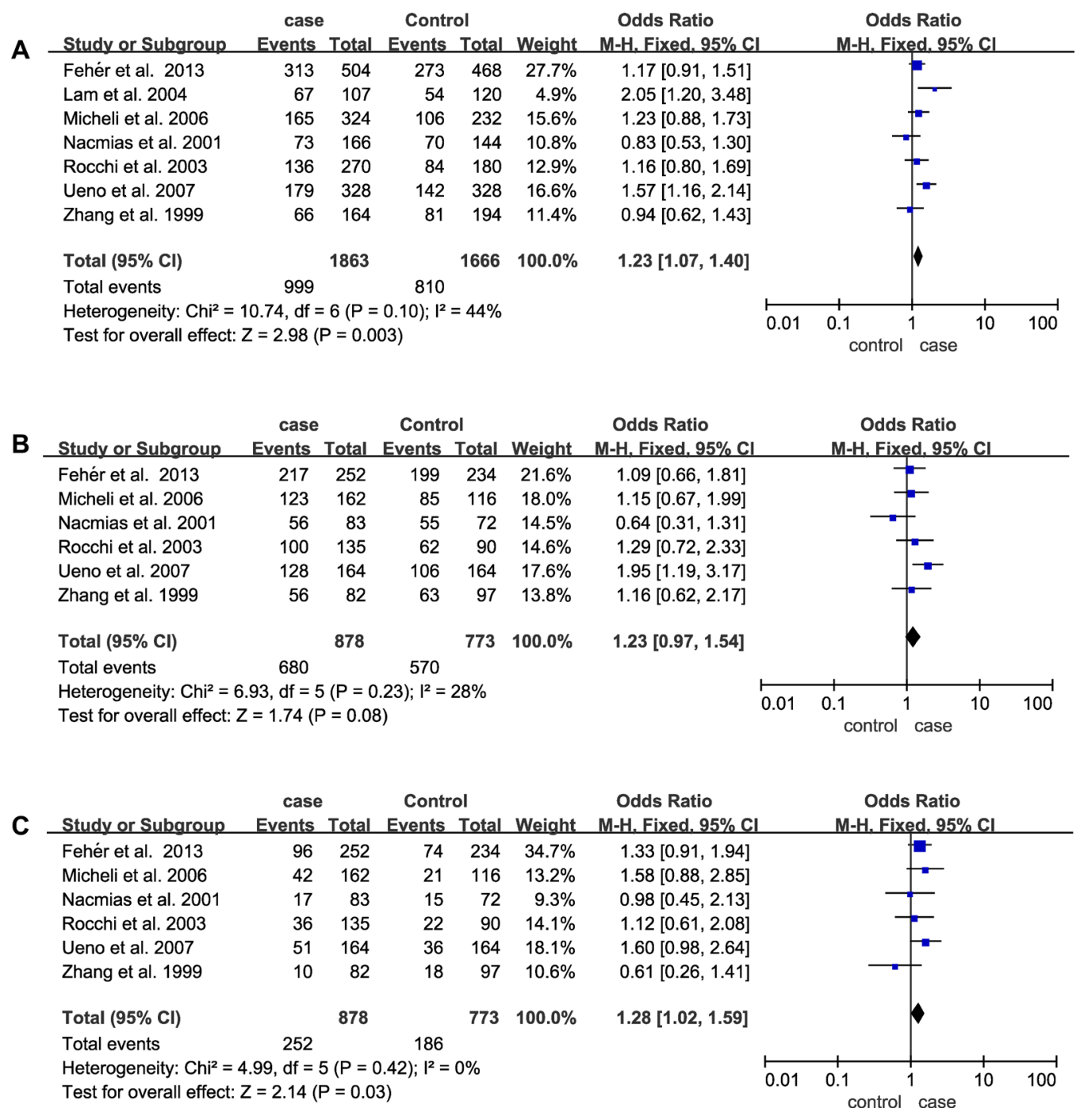

Figure 2: Forest plots of odds ratios for the association between 5HT2A C102T and AD. (A) Allelic model; (B) Dominant model; (C) Recessive model. 
Table 1: Characteristics of eligible studies included in the meta-analysis

\begin{tabular}{|c|c|c|c|c|c|c|c|c|c|c|}
\hline Gene & Author (year) & Ethnicity & $\begin{array}{l}\text { Number } \\
\text { of cases }\end{array}$ & $\begin{array}{l}\text { Number of } \\
\text { controls }\end{array}$ & Age(case/control) & M/F(case: control) & source & result & HWE & $\begin{array}{l}\text { Quality Assessment } \\
\text { (NOS) }\end{array}$ \\
\hline \multirow[t]{7}{*}{$5 \mathrm{HT} 2 \mathrm{~A} \mathrm{C} 102 \mathrm{~T}$} & Lam et al. 2004 & Chinese & 87 & 75 & $77.4 \pm 6.6 / 73.9 \pm 5.6$ & $\mathrm{NA}$ & HB & $>0.05$ & $>0.05$ & 7 \\
\hline & Rocchi et al. 2003 & Itailan & 135 & 90 & $72.4 \pm 7.8 / 70.2 \pm 9.1$ & $45 / 90: 30 / 60$ & HB & $>0.05$ & $>0.05$ & 9 \\
\hline & Micheli et al. 2006 & Itailan & 208 & 116 & $71.8 \pm 9.5 / 70.8 \pm 4.6$ & $76 / 132: 58 / 58$ & PB & $>0.05$ & $>0.05$ & 9 \\
\hline & Nacmias et al. 2001 & Itailan & 83 & 72 & $65.4 \pm 8.4 / 74.5 \pm 25.1$ & NA & HB & $>0.05$ & $>0.05$ & 8 \\
\hline & Ueno et al. 2007 & Japanese & 164 & 164 & $73.1 \pm 8.3 / 73.0 \pm 9.5$ & $52 / 112: 68 / 96$ & HB & $<0.05$ & $>0.05$ & 9 \\
\hline & Zhang et al. 1999 & Chinese & 82 & 97 & $75 \pm 8 / 70 \pm 7$ & NA & HB & $>0.05$ & $>0.05$ & 7 \\
\hline & Fehér et al.2013 & Hungarian & 252 & 234 & $75.2 \pm 7.4 / 74.6 \pm 6.9$ & $118 / 134: 110 / 124$ & HB & $<0.05$ & $>0.05$ & 9 \\
\hline \multirow[t]{16}{*}{ 5HTTLPR L/S } & Kunugi et al. 2000 & Japanese & 123 & 326 & $79 \pm 6 / 57 \pm 8$ & $35 / 88: 151 / 185$ & NA & $>0.05$ & $>0.05$ & 7 \\
\hline & Ha et al 2004 & Korean & 65 & 43 & $74.9 \pm 6.9 / 73.1 \pm 3.8$ & $27 / 38: 20 / 41$ & HB & $>0.05$ & $>0.05$ & 9 \\
\hline & Tsai et al.2001 & Chinese & 136 & 175 & $72.6 \pm 5.3 / 71.5 \pm 6.4$ & $76 / 60: 75 / 102$ & HB & $>0.05$ & $>0.05$ & 9 \\
\hline & Ueki et al. 2007 & Japanese & 200 & 200 & $73.3 \pm 7.9 / 72.6 \pm 8.8$ & $66 / 134: 7 / 127$ & HB & $>0.05$ & $>0.05$ & 9 \\
\hline & Fehér et al.2013 & Hungarian & 252 & 234 & $75.2 \pm 7.4 / 74.6 \pm 6.9$ & $118 / 134: 110 / 124$ & HB & $>0.05$ & $>0.05$ & 9 \\
\hline & Lorenzi et al. 2010 & Itailan & 218 & 54 & $75.49 \pm 8.28 / 66.79 \pm 6.99$ & $77 / 141: 28 / 26$ & HB & $<0.05$ & $>0.05$ & 9 \\
\hline & Forero et al. 2006 & Colombian & 106 & 97 & $73.3 \pm 8.8 / 72.2 \pm 8.7$ & NA & HB & $>0.05$ & $>0.05$ & 7 \\
\hline & Grünblatt et al. 2009 & Austrian & 127 & 479 & NA & 49/78:198/281 & HB & $>0.05$ & $>0.05$ & 9 \\
\hline & Hu et al. 2000 & Germany & 50 & 99 & NA & NA & HB & $>0.05$ & $>0.05$ & 7 \\
\hline & Li et al. 1997 & British & 196 & 257 & $82.5 \pm 6.7 / 70.4 \pm 8.5$ & NA & HB & $<0.05$ & $>0.05$ & 8 \\
\hline & Oliveira et al. 1998 & Brazil & 81 & 244 & $70.02 \pm 8.13 / 75.6 \pm 10.2$ & NA & NA & $<0.05$ & $>0.05$ & 7 \\
\hline & Polito et al. 2011 & Itailan & 235 & 207 & $78.6 \pm 9.8 / 77.0 \pm 9.3$ & $74: 161: 69: 138$ & $\mathrm{HB}$ & $<0.05$ & $>0.05$ & 9 \\
\hline & Seripa et al. 2008 & Itailan & 105 & 114 & $78.42 \pm 7.46 / 78.42 \pm 7.46$ & $34 / 71: 69 / 45$ & PB & $>0.05$ & $>0.05$ & 9 \\
\hline & Sukonick et al. 2001 & American & 58 & 79 & $79.0 \pm 8.0 / 73.1 \pm 8.0$ & $26 / 32: 29 / 50$ & HB & $<0.05$ & $>0.05$ & 9 \\
\hline & Zill et al. 2000 & Germany & 84 & 118 & $73 \pm 9 / 47 \pm 12$ & $36 / 48: 55 / 63$ & NA & $>0.05$ & $>0.05$ & 8 \\
\hline & Micheli et al. 2006 & Itailan & 208 & 116 & $71.8 \pm 9.5 / 70.8 \pm 4.6$ & $76 / 132: 58 / 58$ & PB & $>0.05$ & $>0.05$ & 9 \\
\hline
\end{tabular}

Abbreviations: 5HT2A: 5-hydroxytryptophan 2A Receptor; 5HTTLPR: 5HTT gene-linked polymorphic region; L: long; S:short; M: male; F; female; HB: hospital based; PB: population based; HWE: HardyWeinberg equilibrium; NOS: Newcastle-Ottawa Scale.

dominant models of 5HT2A (C102T) and AD in Asian subgroup (allelic model: $\mathrm{OR}=1.42 ; 95 \% \mathrm{CI}=1.14-1.78$; dominant model: $\mathrm{OR}=1.60 ; 95 \% \mathrm{CI}=1.09-2.35$ ). $\mathrm{In}$ addition, subgroup analysis stratified by APOE $\varepsilon 4$ revealed that the distributions of allelic contrast $(\mathrm{OR}=1.44 ; 95 \%$ $\mathrm{CI}=1.05-1.99)$ and dominant model $(\mathrm{OR}=2.49 ; 95 \%$ $\mathrm{CI}=1.46-4.25)$ of $5 \mathrm{HT} 2 \mathrm{~A} \mathrm{C} 102 \mathrm{~T}$ were significantly increased in AD subgroup without APOE $\varepsilon 4$, but not in AD subgroup with APOE $\varepsilon 4(p>0.05)$ (Table 2).

\section{Meta-analysis: 5HTTLPR (L/S) and Alzheimer's disease}

For 5HTTLPR (L/S), a total of 16 case-control studies containing 2244 cases and 2842 controls were involved. Nevertheless, the pooled ORs for the allelic contrast (OR $=1.10 ; 95 \% \mathrm{CI}=0.76-1.60)$, dominant model $(\mathrm{OR}=1.02$; $95 \% \mathrm{CI}=0.81-1.27)$ and recessive model $(\mathrm{OR}=0.87 ; 95 \%$ $\mathrm{CI}=0.65-1.17)$ of $5 \mathrm{HT} 2 \mathrm{~A} \mathrm{C102T}$ failed to show significant associations (Table 3, Figure 3). Furthermore, no significant association was identified from the pooled results when stratified by ethnicities and APOE $\varepsilon 4(p>0.05)$ (Table $3)$. In addition, we also conducted a subgroup analysis by classifying the Caucasian group into two subgroups (Italian and non-Italian) and obtained negative results (Italian: $p=$ $0.34, \mathrm{OR}=0.8695 \% \mathrm{CI}=0.64-1.17$; non-Italian: $p=0.39$, $\mathrm{OR}=1.3595 \% \mathrm{CI}=0.68-2.69$ ).

\section{Test of heterogeneity}

Considering the great heterogeneity among studies, the random-effect model was applied. Heterogeneity was found for the 5HT2A allelic and recessive models of 5HT2A C102T and AD in Asian subgroup and subgroups without APOE $\varepsilon 4$ (Table 2). The heterogeneity in this polymorphism was contributed mainly by Zhang et al. Removal of this study from meta-analysis gave $0 \%(p$ $>0.05$ ) (Allelic contrast: Asian: $p=0.40$; APOE $\varepsilon 4+$ : not available (NA); recessive model: Asian: NA; APOE $\varepsilon 4+$ : NA) heterogeneity and the result remained none significant, which showed that it had the highest effect on the correction of 5HT2A and AD. Furthermore, subgroup analysis stratified by ethnicities and APOE $\varepsilon 4$ was performed and showed no obvious difference (Ethnicity: $p$ $=0.1$; APOE $\varepsilon 4: p=0.55)$, implying that the ethnicity and APOE $\varepsilon 4$ exerted no influence on the association between the 5HT2A C102T polymorphism and risk of AD.

Significant heterogeneities were also found in allelic, dominant, and recessive models of 5HTTLPR (L/S) (Table 3). The heterogeneity in this polymorphism was contributed mainly by Sukonick et al., Gru"nblatt et al., and Tsai et al. Removal of these studies from meta-analysis gave $0-47 \%$ heterogeneities $(p>0.05)$. And subgroup analysis stratified by ethnicity and APOE $\varepsilon 4$ was performed and showed no obvious difference (Ethnicity: $p=0.11$; APOE $\varepsilon 4: p=$ 
Table 2: The association between 5HT2A C102T and Alzheimer's disease

\begin{tabular}{|c|c|c|c|c|c|c|c|c|c|}
\hline \multirow{2}{*}{$\begin{array}{l}\text { SNPs } \\
\text { (minor } \\
\text { allele) }\end{array}$} & \multirow{2}{*}{ Genetic Model } & \multirow{2}{*}{$\begin{array}{c}\text { Number of } \\
\text { studies }\end{array}$} & \multicolumn{2}{|c|}{ Numbers } & \multicolumn{2}{|c|}{ Test of association } & \multirow[b]{2}{*}{ Model } & \multicolumn{2}{|c|}{ Test of heterogeneity } \\
\hline & & & case & control & OR $[95 \% \mathrm{CI}]$ & $p$-Value & & $P$ value & $I^{2}(\%)$ \\
\hline \multirow[t]{18}{*}{$5 \mathrm{HT} 2 \mathrm{~A}(\mathrm{C})$} & Allelic(C) & & & & & & & & \\
\hline & total & 7 & 1863 & 1666 & $1.23[1.07,1.40]$ & 0.003 & F & 0.10 & 44 \\
\hline & Asian & 3 & 599 & 642 & $1.42[1.14,1.78]$ & 0.002 & $\mathrm{R}$ & 0.05 & 66 \\
\hline & Caucasian & 4 & 1264 & 1024 & $1.13[0.95,1.33]$ & 0.16 & $\mathrm{~F}$ & 0.54 & 0 \\
\hline & With APOE $\varepsilon 4$ & 2 & 256 & 102 & $0.98[0.28,3.38]$ & 0.94 & $\mathrm{R}$ & 0.01 & 84 \\
\hline & Without APOE $\varepsilon 4$ & 2 & 236 & 420 & $1.44[1.05,1.99]$ & 0.02 & F & 0.75 & 0 \\
\hline & $\operatorname{Dominant}(\mathrm{CC}+\mathrm{CT} / \mathrm{TT})$ & & & & & & & & \\
\hline & total & 6 & 878 & 773 & $1.23[0.97,1.54]$ & 0.08 & F & 0.23 & 28 \\
\hline & Asian & 2 & 246 & 261 & $1.60[1.09,2.35]$ & 0.02 & F & 0.20 & 38 \\
\hline & Caucasian & 4 & 632 & 512 & $1.05[0.79,1.40]$ & 0.72 & F & 0.49 & 0 \\
\hline & With APOE $\varepsilon 4$ & 2 & 128 & 51 & $0.73[0.35,1.52]$ & 0.39 & F & 0.17 & 48 \\
\hline & Without APOE $\varepsilon 4$ & 2 & 118 & 210 & $2.49[1.46,4.25]$ & 0.0008 & $\mathrm{~F}$ & 0.79 & 0 \\
\hline & $\operatorname{Recessive}(\mathrm{CC} / \mathrm{CT}+\mathrm{TT})$ & & & & & & & & \\
\hline & total & 6 & 878 & 773 & $1.28[1.02,1.59]$ & 0.03 & $\mathrm{~F}$ & 0.42 & 0 \\
\hline & Asian & 2 & 246 & 261 & $1.24[0.81,1.88]$ & 0.32 & $\mathrm{R}$ & 0.05 & 74 \\
\hline & Caucasian & 4 & 632 & 512 & $1.29[0.99,1.68]$ & 0.06 & $\mathrm{~F}$ & 0.76 & 0 \\
\hline & With APOE $\varepsilon 4$ & 2 & 128 & 51 & $1.84[0.11,29.95]$ & 0.67 & $\mathrm{R}$ & 0.009 & 85 \\
\hline & Without APOE $\varepsilon 4$ & 2 & 118 & 210 & $1.01[0.59,1.73]$ & 0.98 & $\mathrm{~F}$ & 0.42 & 0 \\
\hline
\end{tabular}

Abbreviations: 5HT2A: 5-hydroxytryptophan 2A Receptor; APOE; Apolipoprotein E; R: random model; F: fixed model; OR: odds ratios; CIs: confidence intervals.

Table 3: The association between 5HTTLPR and Alzheimer's disease

\begin{tabular}{|c|c|c|c|c|c|c|c|c|c|}
\hline \multirow{2}{*}{$\begin{array}{l}\text { SNPs } \\
\text { (minor allele) }\end{array}$} & \multirow{2}{*}{ Genetic Model } & \multirow{2}{*}{$\begin{array}{c}\text { Number of } \\
\text { studies }\end{array}$} & \multicolumn{2}{|c|}{ Numbers } & \multicolumn{2}{|c|}{ Test of association } & \multirow{2}{*}{ Model } & \multicolumn{2}{|c|}{ Test of heterogeneity } \\
\hline & & & case & control & OR $[95 \% \mathrm{CI}]$ & $p$-Value & & $P$ value & $I^{2}(\%)$ \\
\hline \multirow[t]{18}{*}{ 5HTTLPR (L) } & Allelic(L) & & & & & & & & \\
\hline & total & 16 & 4350 & 5764 & $1.10[0.76,1.60]$ & 0.62 & $\mathrm{R}$ & $<0.00001$ & 94 \\
\hline & Asian & 4 & 1048 & 1388 & $0.93[0.66,1.31]$ & 0.67 & $\mathrm{R}$ & 0.06 & 60 \\
\hline & Caucasian & 12 & 3302 & 4376 & $1.16[0.72,1.85]$ & 0.54 & $\mathrm{R}$ & $<0.00001$ & 96 \\
\hline & With APOE $\varepsilon 4$ & 5 & 628 & 330 & $1.31[0.69,2.48]$ & 0.41 & $\mathrm{R}$ & 0.02 & 65 \\
\hline & Without APOE $\varepsilon 4$ & 5 & 756 & 1188 & $1.50[0.87,2.59]$ & 0.61 & $\mathrm{~F}$ & 0.18 & 36 \\
\hline & Dominant $(\mathrm{LL}+\mathrm{LS} / \mathrm{SS})$ & & & & & & & & \\
\hline & total & 14 & 1884 & 2399 & $1.02[0.81,1.27]$ & 0.88 & $\mathrm{R}$ & 0.01 & 53 \\
\hline & Asian & 4 & 524 & 744 & $1.09[0.84,1.40]$ & 0.52 & $\mathrm{~F}$ & 0.92 & 0 \\
\hline & Caucasian & 10 & 1360 & 1655 & $1.01[0.73,1.40]$ & 0.96 & $\mathrm{R}$ & 0.002 & 66 \\
\hline & With APOE $\varepsilon 4$ & 5 & 332 & 165 & $1.42[0.86,2.34]$ & 0.17 & $\mathrm{~F}$ & 0.36 & 9 \\
\hline & Without APOE $\varepsilon 4$ & 5 & 378 & 594 & $0.94[0.58,1.52]$ & 0.81 & $\mathrm{R}$ & 0.05 & 58 \\
\hline & Recessive(LL/LS+SS) & & & & & & & & \\
\hline & total & 15 & 2098 & 2453 & $0.87[0.65,1.17]$ & 0.36 & $\mathrm{R}$ & $<0.0001$ & 70 \\
\hline & Asian & 4 & 524 & 744 & $1.10[0.68,1.78]$ & 0.69 & $\mathrm{~F}$ & 0.88 & 0 \\
\hline & Caucasian & 11 & 1574 & 1709 & $0.83[0.59,1.17]$ & 0.29 & $\mathrm{R}$ & $<0.00001$ & 78 \\
\hline & With APOE $\varepsilon 4$ & 5 & 332 & 164 & $0.65[0.36,1.18]$ & 0.16 & $\mathrm{~F}$ & 0.78 & 0 \\
\hline & Without APOE $\varepsilon 4$ & 5 & 378 & 594 & $0.91[0.64,1.30]$ & 0.60 & $\mathrm{~F}$ & 0.30 & 18 \\
\hline
\end{tabular}

Abbreviations: 5HTTLPR: 5HTT gene-linked polymorphic region; L: long; S:short; APOE; Apolipoprotein E; R: random model; F: fixed model;

OR: odds ratios; CIs: confidence intervals. 


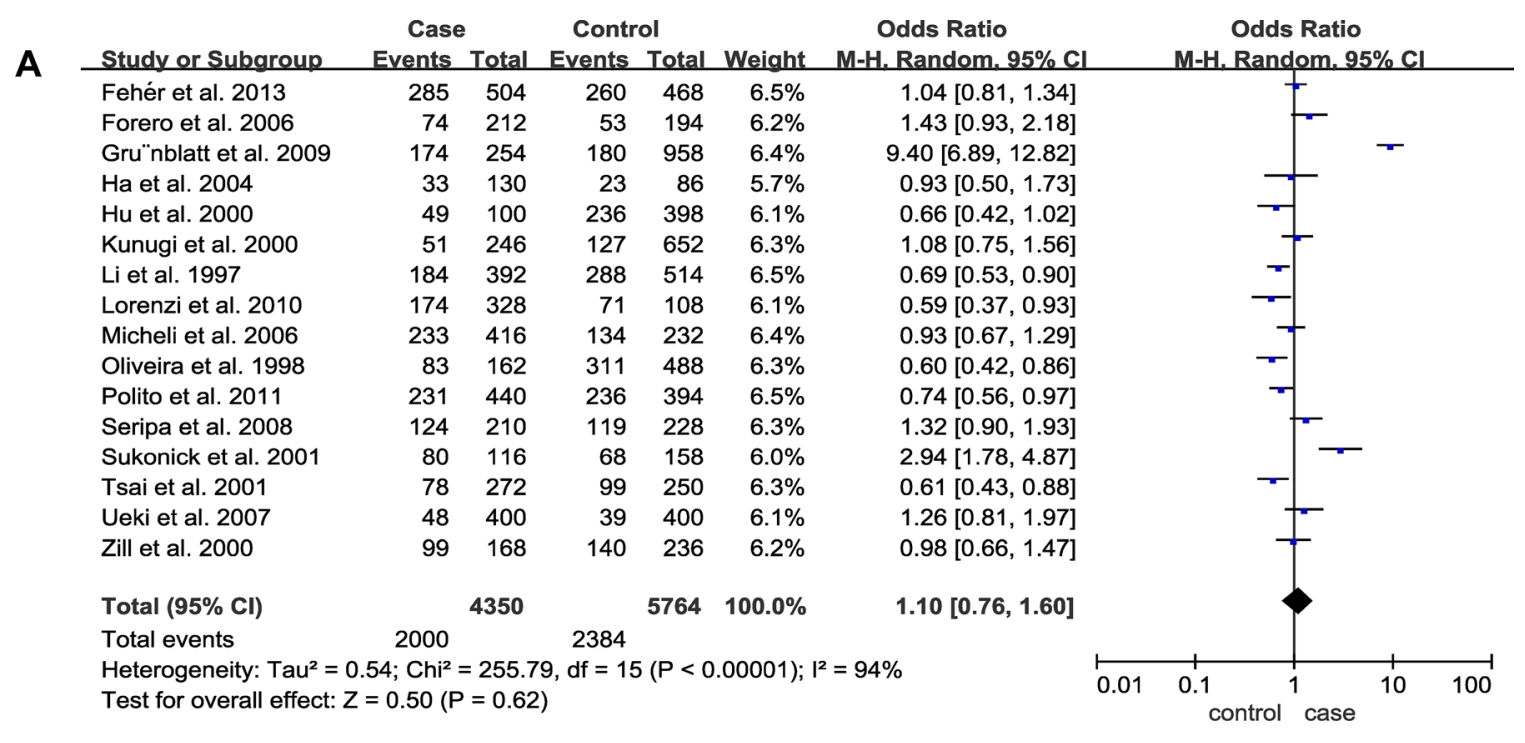

\section{Case Control Odds Ratio Odds Ratio}

B Study or Subgroup Events Total Events Total Weight M-H. Random, 95\% Cl M-H, Random, 95\% Cl

$\begin{array}{lrrrrrr}\text { Fehér et al. 2013 } & 206 & 252 & 188 & 234 & 9.1 \% & 1.10[0.70,1.73] \\ \text { Forero et al. 2006 } & 53 & 106 & 39 & 97 & 7.6 \% & 1.49[0.85,2.59] \\ \text { Ha et al. 2004 } & 30 & 65 & 20 & 43 & 5.3 \% & 0.99[0.46,2.13] \\ \text { Hu et al. 2000 } & 37 & 50 & 169 & 199 & 5.6 \% & 0.51[0.24,1.06] \\ \text { Kunugi et al. 2000 } & 44 & 123 & 112 & 326 & 9.4 \% & 1.06[0.69,1.64] \\ \text { Li et al. 1997 } & 137 & 196 & 205 & 257 & 9.4 \% & 0.59[0.38,0.91] \\ \text { Micheli et al. 2006 } & 167 & 208 & 86 & 116 & 7.9 \% & 1.42[0.83,2.43] \\ \text { Oliveira et al. 1998 } & 65 & 81 & 207 & 244 & 6.5 \% & 0.73[0.38,1.39] \\ \text { Polito et al. 2011 } & 169 & 220 & 160 & 197 & 8.8 \% & 0.77[0.48,1.23] \\ \text { Seripa et al. 2008 } & 85 & 105 & 86 & 114 & 6.5 \% & 1.38[0.72,2.64] \\ \text { Sukonick et al. 2001 } & 57 & 58 & 53 & 79 & 1.1 \% & 27.96[3.67,213.34] \\ \text { Tsai et al. 2001 } & 62 & 136 & 79 & 175 & 9.1 \% & 1.02[0.65,1.60] \\ \text { Ueki et al. 2007 } & 41 & 200 & 34 & 200 & 8.3 \% & 1.26[0.76,2.08] \\ \text { Zill et al. 2000 } & 71 & 84 & 100 & 118 & 5.3 \% & 0.98[0.45,2.13] \\ & & & & & & \\ \text { Total (95\% Cl) } & & 1884 & & 2399 & 100.0 \% & 1.02[0.81,1.27] \\ \text { Total events } & 1224 & & 1538 & & & \end{array}$

Heterogeneity: Tau $^{2}=0.09 ; \mathrm{Chi}^{2}=27.44, \mathrm{df}=13(P=0.01) ; I^{2}=53 \%$

Test for overall effect: $Z=0.15(P=0.88)$

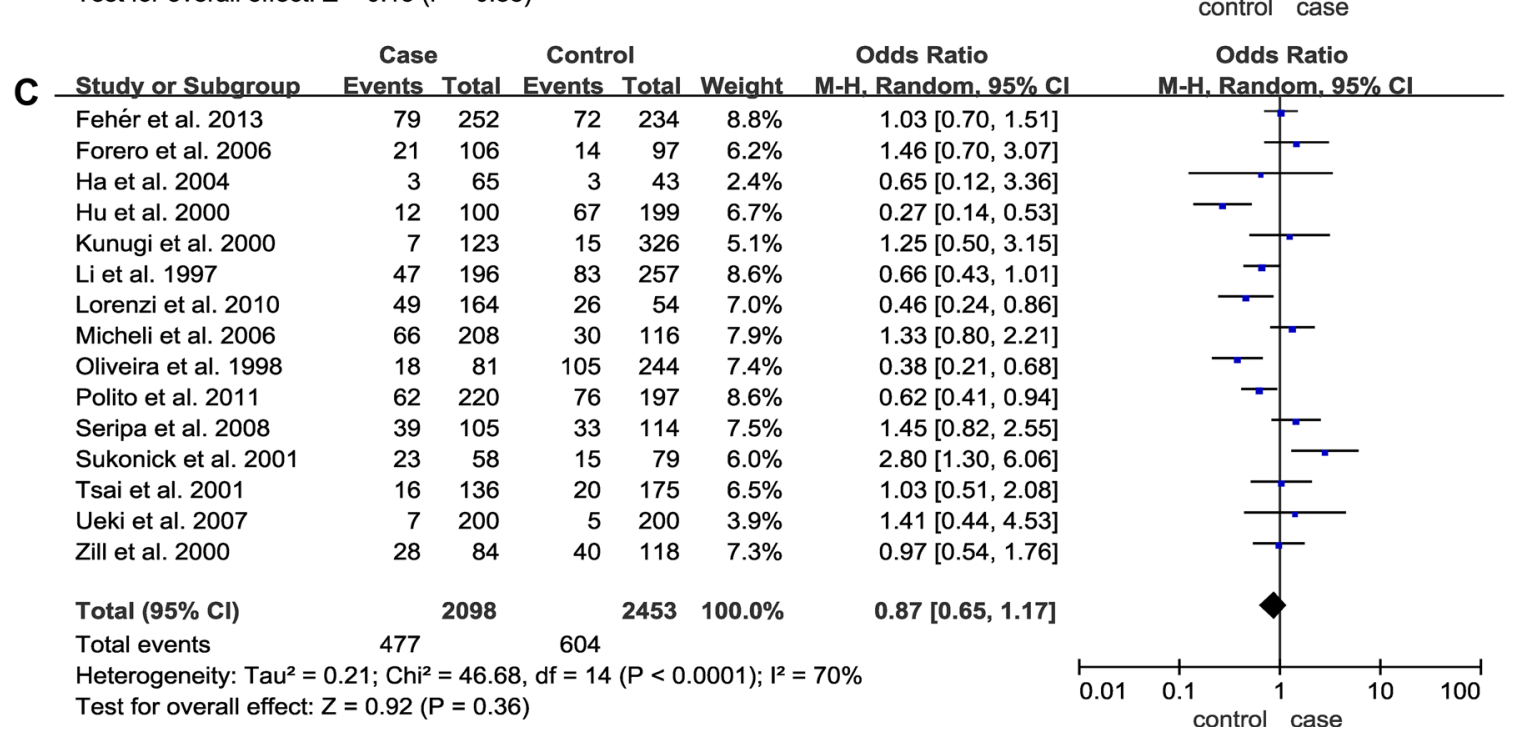

Figure 3: Forest plots of odds ratios for the association between 5HTTLPR (L/S) and AD. (A) Allelic model; (B) Dominant model; (C) Recessive model. 
0.40), implying that the ethnicity and APOE $\varepsilon 4$ exerted no influence on the association between the 5HTTLPR (L/S) polymorphism and risk of AD.

\section{Sensitivity analysis and publication bias}

Sensitivity analysis which excluded the influence of a single study on the overall risk estimate by excluding one study at a time was confirmed. The ORs were not significantly altered in 5HT2A C and 5HTTLPR L (Figure 4). These evidences indicated that the present results were statistically stable and reliable. Funnel plots and Egger's test were performed to assess publication bias. The results revealed that there was no obvious publication bias in overall analysis for 5HT2A C $\left(\mathrm{p}_{\text {egger }}=0.955\right)$ and 5HTTLPR $\mathrm{L}\left(\mathrm{p}_{\text {egger }}=0.924\right)$ (Figure 5). The shape of Begg's funnel plot did not reveal any obvious asymmetry (Figure 5),

\section{DISCUSSION}

The combined results in this meta-analysis indicated that the allelic and dominant models of 5HT2A C102T
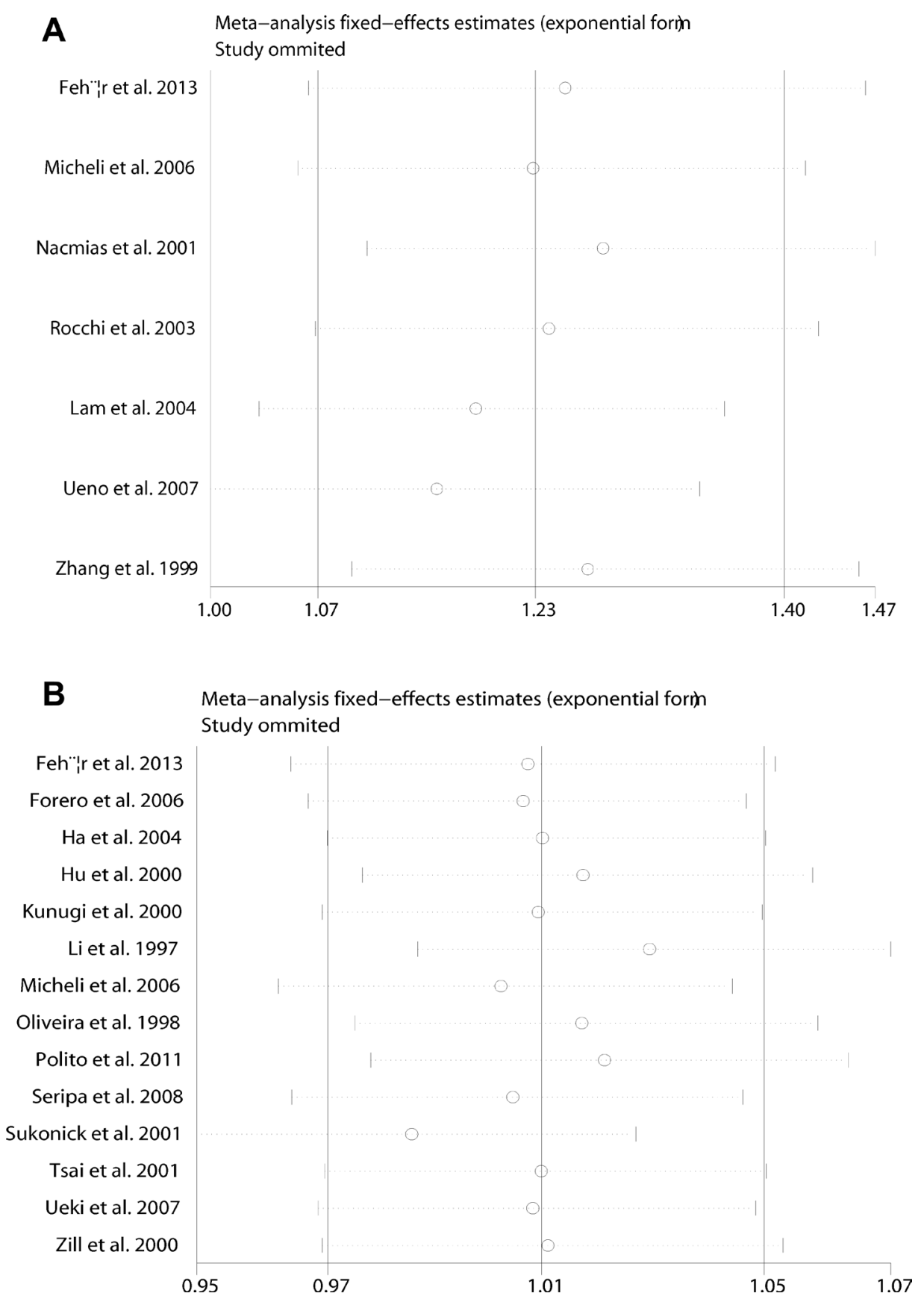

Figure 4: Sensitivity analyses between allelic models of 5HT2A C102T and 5HTTLPR (L/S) and AD. (A) 5HT2A C102T; (B) 5HTTLPR (L/S). 


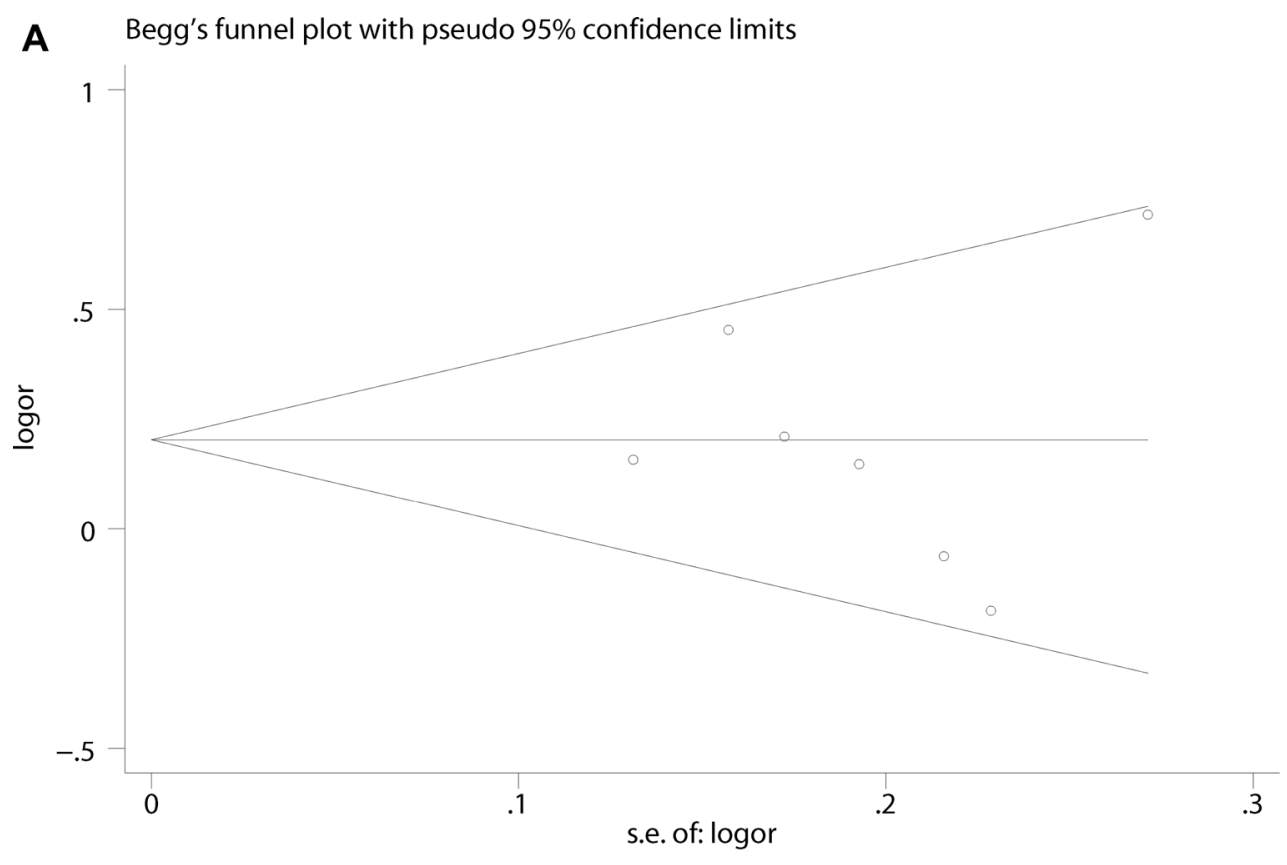

Egger' s test for 5HT2A C102T

\begin{tabular}{lllllll}
\hline Std_Eff & Coef. & Std. Err. & $\mathrm{t}$ & \multicolumn{2}{c}{$\mathrm{P}>|\mathrm{t}|$} & \multicolumn{2}{c}{ [95\% Conf. Interval] } \\
\hline slope & .0201755 & .0960908 & 0.21 & 0.844 & -.2466153 & .2869662 \\
bias & .3044066 & 1.484507 & 0.21 & 0.848 & -3.817247 & 4.42606 \\
\hline
\end{tabular}

B Begg's funnel plot with pseudo $95 \%$ confidence limits

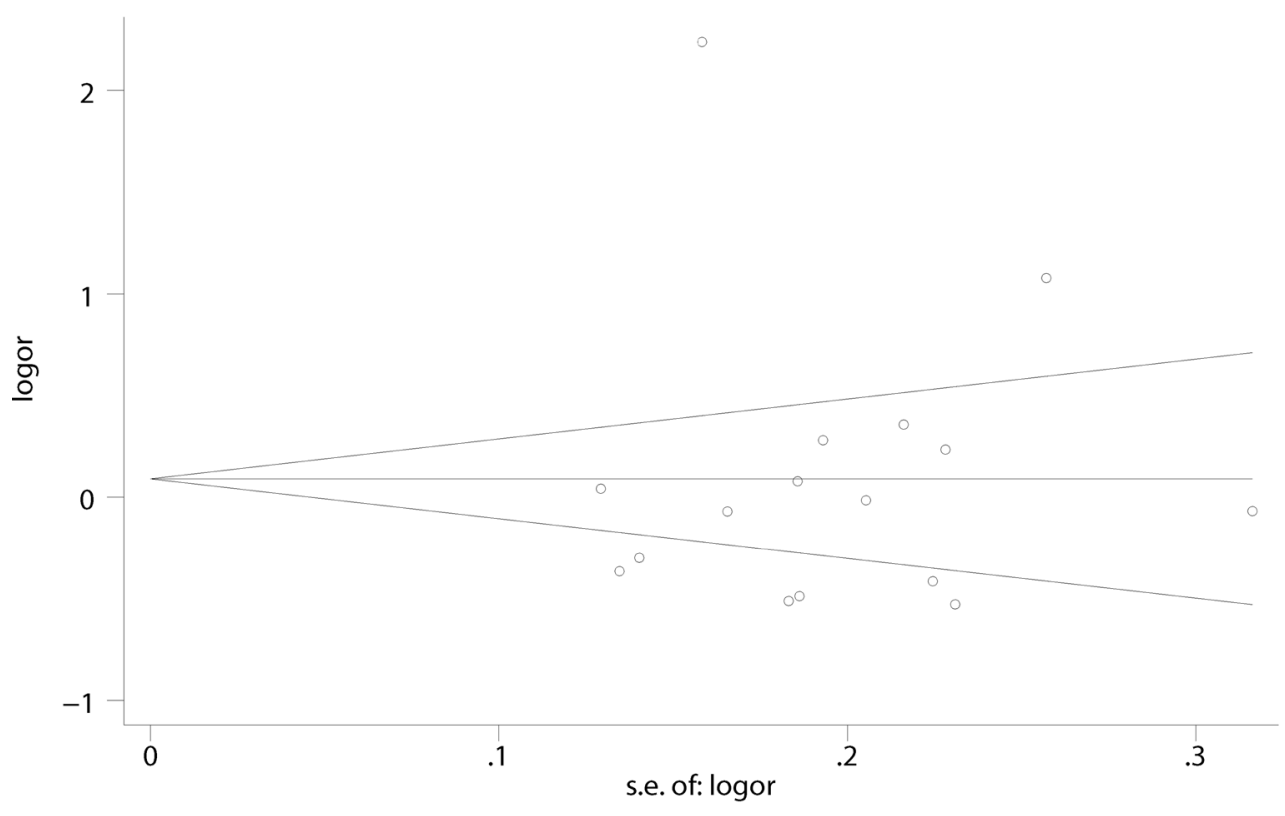

Egger' s test for 5HTTLPR L/S

\begin{tabular}{llllllr}
\hline Std_Eff & Coef. & Std. Err. & $\mathrm{t}$ & $\mathrm{P}>|\mathrm{t}|$ & \multicolumn{2}{c}{ [95\% Conf. Interval] } \\
\hline slope & .0082267 & .8537761 & 4.698138 & 0.992 & -1.822941 & -1.822941 \\
bias & .456617 & 4.698138 & 0.10 & 0.924 & -1.822941 & -1.822941 \\
\hline
\end{tabular}

Figure 5: Publication biases of literatures for 5HT2A C102T and 5HTTLPR (L/S) were tested by Begg's funnel plot and Egger's test. (A) 5HT2A C102T; (B) 5HTTLPR (L/S). 
were significantly associated with increased risk of AD among Asians and patients without APOE $\varepsilon 4$. However, the present study failed to prove the hypothesis that the 5 HTTLPR (L/S) was associated with AD.

The 5HT2A gene, which codes for the serotonin receptor type $2 \mathrm{~A}$, is located at 13q14-q21 [48]. The C/C genotype of 5HT2A C102T carriers showed a significant, 2-fold increased risk when compared to those who carrying the $\mathrm{C}$ or the $\mathrm{T}$ allele [49]. Increasing evidence revealed the 5HT2A C102T was a risk factor in many psychiatric diseases such as bipolar affective disorder, schizophrenia, AD, as well as BPSD in AD [50-52]. The results of the meta-analysis revealed significant associations between the allelic and dominant models of 5HT2A C102T and AD, However, the exact biological mechanism that the 5HT2A gene polymorphisms influence susceptibility to AD remains unclear. Subgroup analysis stratified by ethnicities revealed the AD risk increased significantly for allelic and dominant models of 5HT2A C102T in Asian population. Notable, three studies [25, 38-39] investigated the association between 5HT2A C102T and AD in Asian population. And two of them observed negative results. This discrepancy in individual studies and combined analysis may due to the limited sample size in individual studies. Furthermore, the subgroup analysis stratified by APOE $\varepsilon 4$ in the present meta-analysis also indicated the allelic and dominant models of 5HT2A C102T increase the risk of $\mathrm{AD}$ in subgroup without APOE \&4. However, there were only two studies [38-39] included in subgroup analysis, which might cause insufficient power to detect slight association. To identify the 5HT2A C102T to be a specific risk factor for $\mathrm{AD}$ in Asian subjects and subgroup without APOE $\varepsilon 4$, future larger-scale studies are necessary.

A functional polymorphism in the 5- regulatory promoter region, termed 5-HTTLPR, has been investigated in psychosis, mood disorder, BPSD, affective disorder, and AD [53-56]. 5-HTTLPR S allele leads to a decrease of 5-HTT mRNA transcription, 5-HTT ligand binding, and 5-HT uptake than 5-HTTLPR L allele [57]. However, the precise relationship between 5-HTTLPR $(\mathrm{L} / \mathrm{S})$ polymorphism and serotonin levels is still unclear. To date, a total of 16 studies have detected genetic association between 5-HTTLPR (L/S) and the risk of AD. And, 5 studies reported positive results [1, 31-33, 45]. We noticed that Polito et al. [33] has conducted a case-control and meta-analysis study with 13 individual studies and showed no significant association between the 5HTTLPR S allele and the risk of AD. Interestingly, we included 16 studies and reported negative results for the correction of allelic, dominant and recessive models of 5-HTTLPR (L/S) and AD as well. For the significant heterogeneity among studies, we introduced subgroup analysis by ethnicities and APOE $\varepsilon 4$ and showed no association between 5-HTTLPR (L/S) and AD. We also investigated the association between 5-HTTLPR (L/S) and AD in Italian and non-Italian subgroups, and obtained similar results conducted by Polito et al [33]. All these negative results indicate the 5-HTTLPR (L/S) might not be the susceptible factor for AD.

Nonetheless, limitations also need to be acknowledged in our meta-analysis. Firstly, we enrolled a particularly small number of studies analyzing for association between the 5HT2A C102T and AD (7 casecontrol studies), which may result in an insufficient power for identifying relationship of 5HT2A C102T and AD risk. Secondly, we involved only Asian and Caucasian populations in the present study. Other populations such as African were not included. However, we could not assess the association in African population for lack of studies. Therefore, future studies on various ethnicities are needed. Thirdly, further subtle adjusted analysis by other co-variants such as ages, gender, education level, and life style should be carried out to obtain a more precise evaluation. Fourthly, AD was a progressive neurodegenerative disease with age and gender bias. It is necessary to analysis the genetic association between the 5HT2A $(\mathrm{C} 102 \mathrm{~T})$ and 5HTTLPR $(\mathrm{L} / \mathrm{S})$ in subgroups stratified by age or gender.

In conclusion, our meta-analysis suggests that 5HT2A C102T may increase susceptibility to AD in Asian population and subgroup without APOE $\varepsilon 4$ in both allelic and dominant models. And, the 5-HTTLPR (L/S) might not be the risk factor for AD. However, large-scale studies with more subjects are warranted to confirm these findings.

\section{MATERIALS AND METHODS}

\section{Literature search strategy}

This meta-analysis followed the Cochrane collaboration definition and PRISMA 2009 guidelines for meta-analysis and systematic review. Literatures search on PubMed, Embase, Web of Science, the Cochrane Library databases and Chinese National Knowledge Infrastructure (CNKI) was performed to investigate all relevant publications exploring the relationship between 5HT2A and 5HTTLPR polymorphisms and the risk of AD (up to June 1, 2017). The search terms were following: "5HT2A" or "neurotransmitter 5 hydroxytryptophan 2A Receptor" or "serotonin receptor $2 \mathrm{~A}$ " or "serotonin 2A Receptor" or "HTR2A" and "polymorphism" or "variant" or "gene mutation" "single nucleotide polymorphism (SNP)" or "gene variation" and "Alzheimer's disease" or "AD" and "promoter region of the serotonin transporter gene" or "5HTTLPR". No language was limited. Meanwhile, other potentially relevant literatures were identified by crossreferences within eligible studies. 


\section{Inclusion/exclusion criteria}

1) Investigating the association between $5 \mathrm{HT} 2 \mathrm{~A}$ (C102T), 5HTTLPR (L/S) polymorphisms and susceptible of AD. 2) The study was case-control and/or cohort designed. 3) Sufficient published data for calculating an odds ratio (OR) with $95 \%$ confidence interval (CI). 4) The genotype distributions in control groups were in the Hardy-Weinberg equilibrium (HWE).

\section{Exclusion criteria}

1) Duplicated studies, abstracts, letters or reviews. 2) Studies without controls. 3) Control group did not confirm to Hardy-Weinberg equilibrium (HWE). 4) No available genotype data.

\section{Data extraction and quality assessment}

Data abstraction was performed independently by $\mathrm{L}$. T. and Y. W. The following information from each study was summarized: first author, year, ethnicity, numbers of cases and controls, mean age and gender, methods of genotyping, sample source, Hardy-Weinberg equilibrium (HWE) for control groups. All included studies were evaluated using the Newcastle-Ottawa Scale (NOS) independently by L. T. and Y. W. C. Any discrepancies in the assessment were resolved by J. M. L.

\section{Statistical analyses}

The odds ratio (OR) and $95 \%$ confidence interval $(95 \% \mathrm{CI})$ were calculated for evaluating the association between 5HT2A T102C, 5HTTLPR L/S and AD using the RevMan 5 (Oxford, UK) and STATA12.0 (StataCorp, College Station, TX, USA). The pooled ORs were calculated in the allelic, dominant and recessive models. The statistical significance of the OR was determined using the $\mathrm{Z}$ test. Statistical heterogeneity was tested using $\chi^{2}$-based Q test and the $I^{2}$ statistic. When there was no significant heterogeneity across studies $\left(I^{2}<50 \%\right)$, the fixed effect model (Mantel-Haenszel method) was used for meta-analysis. Otherwise, the random effect model (the DerSimonian and Laird method) was used. Sources of heterogeneity were evaluated by stratification analysis of ethnicities and APOE $\varepsilon 4$ allele, according to the study characteristics. Sensitivity analysis was performed to assess the stability of results. The publication bias was detected with Begg's test and Egger's test. $p<0.05$ was considered statistically significant.

\section{CONFLICTS OF INTEREST}

None.

\section{FUNDING}

The work was funded by the key Foundation of the Education Department of Hunan (16A027), the
Foundation of the Education Department of Hunan (15C0513 and 16C0162), and Foundation of the health department of Hunan (B2016096).

\section{REFERENCES}

1. Oliveira JR, Gallindo RM, Maia LG, Brito-Marques PR, Otto PA, Passos-Bueno MR, Morais MA Jr, Zatz M. The short variant of the polymorphism within the promoter region of the serotonin transporter gene is a risk factor for late onset Alzheimer's disease. Mol Psychiatr. 1998; 3:43841. https://doi.org/10.1038/sj.mp.4000417.

2. Da CI, de Labio RW, Rasmussen LT, Viani GA, Chen E, Villares J, Turecki G, Smith MAC, Payao SLM. Change in INSR, APBA2 and IDE Gene Expressions in Brains of Alzheimer's Disease Patients. Curr Alzheimer Res. 2017; 14:760-5. https://doi.org/10.2174/1567205014666170203 100734.

3. Lin E, Tsai SJ, Kuo PH, Liu YL, Yang AC, Cao CF. Association and interaction effects of Alzheimer's diseaseassociated genes and lifestyle on cognitive aging in older adults in a Taiwanese population. Oncotarget. 2017; 8:24077-87. https://doi.org/10.18632/oncotarget.15269.

4. Marioni RE, Campbell A, Hagenaars SP, Nagy R, Amador C, Hayward C, Porteous DJ, Visscher PM, Deary IJ. Genetic Stratification to Identify Risk Groups for Alzheimer's Disease. J Alzheimers Dis. 2017; 57:275-83. https://doi. org/10.3233/JAD-161070.

5. Culverhouse RC, Saccone NL, Horton AC, Ma Y, Anstey KJ, Banaschewski T, Burmeister M, Cohen-Woods S, Etain B, Fisher HL, Goldman N, Guillaume S, Horwood $\mathrm{J}$, et al. Collaborative meta-analysis finds no evidence of a strong interaction between stress and 5-HTTLPR genotype contributing to the development of depression. Mol Psychiatr. 2017 Apr 4. https://doi.org/10.1038/mp. [Epub ahead of print].

6. Michaelson DM. APOE $\varepsilon 4$ : the most prevalent yet understudied risk factor for Alzheimer's disease. Alzheimers \& Alzheimers Dement. 2014; 10:861-68. https://doi. org/10.1016/j.jalz.2014.06.015.

7. Kim J, Basak JM, Holtzman DM. The role of apolipoprotein $\mathrm{E}$ in Alzheimer's disease. Neuron. 2009. 63:287-303. https://doi.org/10.1016/j.neuron.2009.06.026.

8. Dorszewska J, Prendecki M, Oczkowska A, Dezor M, Kozubski W. Molecular basis of familial and sporadic Alzheimer's disease. Curr Alzheimer Res. 2016; 13:952-63. https://doi.org/10.2174/1567205013666160314150501.

9. Naj AC, Jun G, Beecham GW, Wang LS, Vardarajan BN, Buros J, Gallins PJ, Buxbaum JD, Jarvik GP, Crane PK, Larson EB, Bird TD, Boeve BF, et al. Common variants in MS4A4/MS4A6E, CD2uAP, CD33, and EPHA1 are associated with late-onset Alzheimer's disease. Nat Genet. 2011; 43:436-41. https://doi.org/10.1038/ng.801.

10. Rahman MH, Ali MY. The Relationships between Thyroid Hormones and the Brain Serotonin (5-HT) System and 
Mood: Of Synergy and Significance in the Adult Brain- A Review. Faridpur Med Coll. 2015; 9:98-101. https://doi. org/10.3329/fmcj.v9i2.25684.

11. Glick AR. The role of serotonin in impulsive aggression, suicide, and homicide in adolescents and adults: a literature review. Int J Adolesc Med Health. 2015; 27:143-50. https:// doi.org/10.1515/ijamh-2015-5005.

12. Dalley JW, Roiser JP. Dopamine, serotonin and impulsivity. Neuroscience. 2012; 215:42-58. https://doi.org/10.1016/j. neuroscience.2012.03.065.

13. Helton SG, Lohoff FW. Serotonin pathway polymorphisms and the treatment of major depressive disorder and anxiety disorders. Pharmacogenomics. 2015; 16:541-53. https://doi. org/10.2217/pgs.15.15.

14. Normile HJ, Altman HJ. Serotonin, Alzheimer's disease and Learning and Memory in Animals. Alzheimer's disease. 1987:141-56. https://doi.org/10.1007/978-1-4615-6414-0-12.

15. Meneses A. Neural activity, memory, and dementias: serotonergic markers. Behav Pharmacol. 2016; 28:132-41. https://doi.org/10.1097/FBP.0000000000000279.

16. Mizukami K, Ishikawa M, Akatsu H, Abrahamson EE, Ikonomovic MD, Asada T. An immunohistochemical study of the serotonin 1A receptor in the hippocampus of subjects with Alzheimer's disease. Neuropathology. 2011; 31:503-9. https://doi.org/10.1111/j.1440-1789.2010.01193.x.

17. Verdurand M, Zimmer L. Hippocampal 5-HT1A receptor expression changes in prodromal stages of Alzheimer's disease: Beneficial or deleterious. Neuropathology. 2017; 123:446-54. https://doi.org/10.1016/j.neuropharm.

18. Aït AD, Segu L, Buhot MC. Region-specific decrease in 5-HT1A and 5-HT1B binding sites after intra-hippocampal ibotenic acid injections in the rat. Neurosci Lett. 2001; 310:25-8. https://doi.org/10.1016/S0304-3940(01)02080-8.

19. Marner L, Frokjaer VG, Kalbitzer J, Lehei S, Madsen K, Baare WF, Knudsen GM. Loss of serotonin 2A receptors exceeds loss of serotonergic projections in early Alzheimer's disease: a combined [11C] DASB and [18F] altanserinPET study. Neurobiol Aging. 2012; 33:479-87. https://doi. org/10.1016/j.neurobiolaging.2010.03.023.

20. Philibert R, Madan A, Andersen A, Cadoret R, Packer $\mathrm{H}$, Sandhu H. Serotonin transporter mRNA levels are associated with the methylation of an upstream $\mathrm{CpG}$ island. American Journal of Medical Genetics Part B Neuropsychiatric Genetics. 2007; 144B:101-5. https://doi. org/10.1002/ajmg.b.30414.

21. Thome J, Retz W, Baader M, Pesoid B, Hu M, Cowen M, Durany N, Adler G, Henn FA, Rosler M. Association analysis of HTR6, and HTR2A, polymorphisms in sporadic Alzheimer's disease. Am J Med Genet B. 2001; 108:117580. https://doi.org/10.1007/s007020170007.

22. Fehér A, Juhász A, László A, Pákáski M, Kálmán J, Janka Z. Serotonin transporter and serotonin receptor $2 \mathrm{~A}$ gene polymorphisms in Alzheimer's disease. Neurosci Lett. 2013; 534:233-36. https://doi.org/10.1016/j.neulet.2012.12.020.
23. Seripa D, Franceschi M, D’Onofrio G, Panza F, Cascavilla L, Paris F, Placentino G, Matera MG, Solfrizzi V, Pilotto A. Polymorphism $\mathrm{C}$ in the serotonin transporter gene (SLC6A4) in questionable dementia and Alzheimer's disease. Neuroscience Letters. 2008; 438:335-9. https:// doi.org/10.1016/j.neulet.2008.04.076.

24. Norton N, Owen MJ. HTR2A: association and expression studies in neuropsychiatric genetics. Ann Med. 2005; 37:121-9. https://doi.org/10.1080/07853890510037347.

25. Lam LC, Tang NL, Ma SL, Zhang W, Chiu HF. 5-HT2A T102C receptor polymorphism and neuropsychiatric symptoms in Alzheimer's disease. Int J Geriatr Psych. 2004; 19:523-6. https://doi.org/10.1002/gps.1109.

26. Rocchi A, Micheli D, Ceravolo R, Manca ML, Tognoni G, Siciliano G, Murri L. Serotoninergic polymorphisms (5-HTTLPR and 5-HT2A): association studies with psychosis in Alzheimer disease. Genet Test. 2003, 7:30914. https://doi.org/10.1089/109065703322783662.

27. Heils A, Mössner R, Lesch KP. The human serotonin transporter gene polymorphism--basic research and clinical implications. J Neural Transm. 1997; 104:1005-14. https:// doi.org/10.1007/BF01273314.

28. Pinheiro RT, Coelho FM, Silva RA, Pinheiro KA, Oses JP, Quevedo Lde Á, Souza LD, Jansen KO, Zimmermann Peruzatto JM, Manfro GG, Giovenardi M, Almeida SO, Lucion AB. Association of a serotonin transporter gene polymorphism (5-HTTLPR) and stressful life events with postpartum depressive symptoms: a population-based study. J Psychosom Obst Gyn. 2013; 34:29-33. https://doi.org/10 .3109/0167482X.2012.759555.

29. Schneck N, Miller JM, Delorenzo C, Kikuchi T, Sublette ME, Oquendo MA, Mann JJ, Parsey RV. Relationship of the serotonin transporter gene promoter polymorphism (5-HTTLPR) genotype and serotonin transporter binding to neural processing of negative emotional stimuli. J Affect Disorders. 2016; 190:494-8. https://doi.org/10.1016/j.jad.

30. Nomura M, Kaneko M, Okuma Y, Nomura J, Kusumi I, Koyama T, Nomura Y. Involvement of Serotonin Transporter Gene Polymorphisms (5-HTT) in Impulsive Behavior in the Japanese Population. Plos One. 2015; 10:e0119743. https://doi.org/10.1371/journal.pone.0119743.

31. Li T, Holmes C, Sham PC, Vallada H, Birkett J, Kirov G, Lesch KP, Powell J, Lovestone S, Collier D. Allelic functional variation of serotonin transporter expression is a susceptibility factor for late onset Alzheimer's disease. Neuroreport. 1997; 8:683-86. https://doi. org/10.1097/00001756-199702100-00021.

32. Lorenzi C, Marcone A, Pirovano A, Marino E, Cordici F, Cerami C, Delmonte D, Cappa SF, Bramanti P, Smeraldi E. Serotonin transporter and saitohin genes in risk of Alzheimer's disease and frontotemporal lobar dementia: preliminary findings. Neurological Sciences. 2010; 31:741749. https://doi.org/10.1007/s10072-010-0400-8.

33. Polito L, Prato F, Rodilossi S, Ateri E, Galimberti D, Scarpini E, Clerici F, Mariani C, Forloni G, Albani D. A 
Novel Study and Meta-Analysis of the Genetic Variation of the Serotonin Transporter Promoter in the Italian Population Do Not Support a Large Effect on Alzheimer's disease Risk. Int J Alzheimers Dis. 2011; 2011:312341. https://doi. org/10.4061/2011/312341.

34. Kunugi H, Ueki A, Otsuka M, Isse K, Hirasawa H, Kato N, Nabika T, Kobayashi S, Nanko S. Alzheimer's disease and 5-HTTLPR polymorphism of the serotonin transporter gene: no evidence for an association. Am J Med Genet B. 2000; 96:307-9. https://doi.org/10.1002/10968628(20000612)96:3<307:AID-AJMG14>3.0.CO;2-0.

35. Tsai SJ, Hong CJ, Liu TY, Cheng CY, Liu HC. Association study for a functional serotonin transporter gene polymorphism and late-onset Alzheimer's disease for Chinese patients. Neuropsychobiology. 2001; 44:27-30. https://doi.org/10.1159/000054910.

36. Ueki A, Ueno H, Sato N, Shinjo H, Morita Y. Serotonin transporter gene polymorphism and BPSD in mild Alzheimer's disease. J Alzheimers Dis. 2007; 12:245-53. https://doi.org/10.3233/JAD-2007-12306.

37. Nacmias B, Tedde A, Forleo P, Piacentini S, Guarnieri BM, Bartoli A, Petruzzi C, Serio A, Marcon G, Sorbi S. Association between 5-HT2A Receptor Polymorphism and Psychotic Symptoms in Alzheimer's Disease. Bol Psychiatry. 2001; 50:472-75. https://doi.org/10.1016/ S0006-322301114-3.

38. Ueno H, Ueki A, Shinjo H, Shinjo H, Yasuda M, Maeda K, Morita Y. The Relationship Between Serotonin 2A Receptor Gene Polymorphism and Alzheimer's Disease. Acta Med Hyogoensis. 2007; 32:87-93.

39. Zhang MY, Jiang S, Wang $H$. The relation between 5-HT(2A) receptor gene polymorphism and Alzheimer's disease in Chinese. Chinese J Psych. 1999; 32:73-5.

40. Micheli D, Bonvicini C, Rocchi A, Ceravolo R, Mancuso M, Tognoni G, Gennarelli M, Siciliano G, Murri L. No evidence for allelic association of serotonin 2A receptor and transporter gene polymorphisms with depression in Alzheimer disease. J Alzheimers Dis. 2006; 10:371-8. https://doi.org/10.3233/JAD-2006-10405.

41. Ha TM, Cho DM, Park SW, Joo MJ, Lee BJ, Kong BG, Kim JM, Yoon JS, Kim YH. Evaluating associations between 5-HTTLPR polymorphism and Alzheimer's disease for Korean patients. Dement Geriatr Cogn. 2005; 20:31-4. https://doi.org/10.1159/000085071.

42. Forero DA, Arboleda G, Yunis JJ, Pardo R, Arboleda H. Association study of polymorphisms in LRP1, tau and 5-HTT genes and Alzheimer's disease in a sample of Colombian patients. J Neural Transm. 2006; 113:1253-62. https://doi.org/10.1007/s00702-005-0388-z.

43. Grünblatt EO, Zehetmayer S, Bartl J, Löffler C, Wichart I, Rainer MK, Jungwirth S, Bauer P, Danielczyk W, Tragl KH, Riederer P, Fischer P. Genetic risk factors and markers for Alzheimer's disease and/or depression in the VITA study. J Psychiatr Res. 2009; 43:298-308. https://doi.org/10.1016/j. jpsychires.2008.05.008.
44. Hu M, Retz W, Baader M, Pesold B, Adler G Henn FA, Rosler M, Thome J. Promoter polymorphism of the 5-HT transporter and Alzheimer's disease. Neurosci Lett. 2000; 294:63-5. https://doi.org/10.1016/S0304-3940(00)01544-5.

45. Sukonick DL, Pollock BG, Sweet RA, Mulsant BH, Rosen J. The 5-HTTPR S/L polymorphism and aggressive behavior in Alzheimer disease. Arch Neurol. 2001; 58:1425-8. https://doi.org/10.1001/archneur.58.9.1425.

46. Zill P, Padberg F, de Jonge S, Hampel H, Bürger K, Stübner S, Boetsch T, Jürgen Möller H, Ackenheil M. Bondy B Serotonin transporter (5-HTT) gene polymorphism in psychogeriatric patients. Neurosci Lett. 2000; 284:113-5. https://doi.org/10.1016/S0304-3940(00)00994-0.

47. Abou-Setta AM, Mousavi SS, Spooner C, Schouten JR, Pasichnyk D. First-Generation Versus Second-Generation Antipsychotics in Adults: Comparative Effectiveness. Rockville (MD): Agency for Healthcare Research and Quality (US). Appendix G, Newcastle-Ottawa Scale Assessment of Cohort Studies. 2012. Available from: https://www.ncbi.nlm.nih.gov/books/NBK107261/.

48. Zoroglu SS, Erdal ME, Erdal N, Ozen S, Alasehirli B, Sivasli E. No evidence for an association between the $\mathrm{T} 102 \mathrm{C}$ and $1438 \mathrm{G} / \mathrm{A}$ polymorphisms of the serotonin $2 \mathrm{~A}$ receptor gene in attention deficit/hyperactivity disorder in a Turkish population. Neuropsychobiology. 2003; 47:17-20. https://doi.org/10.1159/000068870.

49. Abdolmaleky HM, Yaqubi S, Papageorgis P, Lambert AW, Ozturk S, Sivaraman V, Thiagalingam S. Epigenetic dysregulation of HTR2A in the brain of patients with schizophrenia and bipolar disorder. Schizophr Res. 2011; 129:183-90. https://doi.org/10.1016/j. schres.2011.04.007.

50. Bonnier B, Gorwood P, Hamon M, Sarfati Y, Boni C, Hardy-Bayle MC. Association of 5-HT(2A) receptor gene polymorphism with major affective disorders: the case of a subgroup of bipolar disorder with low suicide risk. Bio Psych. 2002; 51:762-5. https://doi.org/10.1016/S00063223(01)01228-8.

51. Abdolmaleky HM, Faraone SV, Glatt SJ, Tsuang MT. Metaanalysis of association between the T102C polymorphism of the 5HT2a receptor gene and schizophrenia. Schizophr Res. 2004; 67:53-62. https://doi.org/10.1016/S0920-9964(03)00183-X.

52. Pritchard AL. Role of 5HT2A and 5HT2C polymorphisms in behavioural and psychological symptoms of Alzheimer's disease. Neurobiol Aging. 2008; 29:341-7. https://doi. org/10.1007/978-1-60761-941-3-25.

53. Creese B, Ballard C, Jones E. Cognitive impairment in studies of 5HTTLPR and psychosis in Alzheimer's disease: a systematic review. Dement Geriatr Cogn. 2013; 35:15564. https://doi.org/10.1159/000346733.

54. Eun TK, Jeong SH, Lee KY, Kim SH, Ahn YM, Bang YW, Joo EJ. Association between the 5-HTTLPR Genotype and Childhood Characteristics in Mood Disorders. Clin Psychopharm Neu. 2016; 14:88-95. https://doi.org/10.9758/ cpn.2016.14.1.88. 
55. Flirski M, Sobów T, Kłoszewska I. Genetic background of behavioural and psychological symptoms of dementia in Alzheimer's disease. Adv Psychi Neurol. 2010; 19:287-97.

56. Mendlewicz J, Massat I, Souery D, Del-Favero J, Oruc L, Nöthen MM, Blackwood D, Muir W, Battersby S, Lerer B, Segman RH, Kaneva R, Serretti A, et al. Serotonin transporter 5HTTLPR polymorphism and affective disorders: no evidence of association in a large European multicenter study. Eur J Hum Genet. 2004; 12:377-82. https://doi.org/10.1038/sj.ejhg.5201149.
57. Borroni B, Grassi M, Agosti C, Costanzi C, Archetti S, Franzoni S, Caltagirone C, Di Luca M, Caimi L, Padovani A. Genetic correlates of behavioral endophenotypes in Alzheimer disease: Role of COMT, 5-HTTLPR, and APOE, polymorphisms. Neurobiol Aging. 2006; 27:1595-603. https://doi.org/10.1016/j.neurobiolaging.2005.09.029. 